\title{
KAJIAN ASPEK KEBIJAKAN DAN REGULASI DALAM MASALAH PENGELOLAAN LIMBAH CAIR INDUSTRI RUMAH TANGGA
}

\author{
Oleh : P. Nugro Rahardjo \\ Peneliti di Pusat Teknologi Lingkungan, BPPT
}

\begin{abstract}
Water pollution because of the domestic wastewater produced by the local community and their home industries in a big city, such as Jakarta, has already been inviting many environmental problems since the last ten years. Based on the research done by Directorat General Cipta Karya, Public Works Department Rl, domestic wastewater in Jakarta delivers $75 \%$ of all pollutants in surface water pollution. Therefore many things should be done to solve those water pollution problems. A lot of environmentally related rules have established in Indonesia, but they are not able to be optimally implemented because of some weaknesses of the environmental rule contents. One of the solving options is to create a perfect regulation system for wastewater management. The laws for home industry wastewater management, especially in big cities, have to be perfectly completed, mainly in the field of standard, operation and procedure, the wastewater quality standard, the adequate and qualified technology, the landscape and building planning and the institutional coordination. If the all environmental regulations are well synchronized, the law enforcement will be simply implemented. By applying them consistently, the water pollution control will be handled well.
\end{abstract}

\section{Keywrods : Environmental Regulation, Home Industry Waste Water, Institutional Coordination}

\section{PENDAHULUAN}

\subsection{Latar Belakang}

Pencemaran lingkungan yang terjadi dikota-kota besar di Indonesia tampaknya semakin sulit dikendalikan. Sebagai contoh ialah kompleksnya permasalahan dalam mengatasi pencemaran air, khususnya air permukaan. Berdasarkan hasil-hasil penelitian dari berbagai kalangan dalam kurun waktu sepuluh tahun terakhir, baik penelitian yang dilakukan oleh instansi pemerintah ataupun lembaga-lembaga swadaya masyarakat, menunjukkan bahwa pencemaran air sungai di dua kota besar, yaitu Jakarta dan Bandung, didominasi oleh sumber pencemar yang berasal dari daerah pemukiman atau limbah cair domestik. ${ }^{1)}$

Kondisi lingkungan perairan khususnya di Jakarta semakin lama menjadi semakin parah. Hal ini dapat dilihat dari kualitas air sungai-sungai yang mengalir melalui kota Jakarta. Diketahui bahwa sebelum sungai-sungai tersebut memasuki Jakarta, kondisinya memang sudah tercemar sejak dari daerah hulunya, yaitu kawasan pegunungan dan perbukitan di Jawa Barat, khususnya Bandung, Cianjur dan Bogor. Berdasarkan data yang diperoleh dari Dinas PU Propinsi DKI Jakarta tahun 2005, jumlah air buangan secara keseluruhan di DKI Jakarta diperkirakan sebesar $1.816 .113 \mathrm{M}^{3} /$ hari. Jumlah tersebut terbagi menjadi air buangan domestik
1.362.085 $\mathrm{M}^{3} /$ hari, buangan perkantoran dan daerah komersial $272.417 \mathrm{M}^{3} /$ hari dan buangan industri $181.611 \mathrm{M}^{3} /$ hari. Dilihat dari segi jumlah, air limbah domestik (rumah tangga) memberikan kontribusi terhadap pencemaran air sekitar $75 \%$, air limbah perkantoran dan daerah komersial 15 $\%$, dan air limbah industri hanya sekitar $10 \%$. Sedangkan dilihat dari beban polutan organiknya, sebenarnya air limbah rumah tangga sekitar 70 $\%$, air limbah perkantoran $14 \%$, dan air limbah industri memberikan kontribusi $16 \%{ }^{2)}$ Dengan demikian air limbah rumah tangga adalah penyumbang yang terbesar terhadap pencemaran air di wilayah DKI Jakarta.

Untuk mengatasi pencemaran lingkungan, khususnya pencemaran terhadap perairan di DKI Jakarta, banyak hal yang harus dilakukan. Salah satu upaya yang dapat dijadikan langkah prioritas adalah penyempurnaan sistem peraturanperaturan atau langkah regulasi-deregulasi di bidang pencemaran lingkungan, khususnya pencemaran air. Karena itu sangat dibutuhkan satu kajian khusus yang mengulas segala kondisi dan permasalahan yang menyangkut pencemaran air dan cara-cara penanggulangannya, terutama dilihat dari aspek hukumnya.

\subsection{Perkembangan Masalah Pencemaran Air di Jakarta}

Berdasarkan hasil kegiatan survey lapangan langsung ke beberapa kecamatan di 
dalam wilayah Jakarta Timur, diperoleh gambaran bahwa situasi dan kondisi suatu daerah yang semula memang diperuntukkan sebagai daerah pemukiman ternyata sudah tidak sesuai lagi dengan apa yang telah digariskan dalam Rencana Umum Tata Ruang Wilayah. Artinya banyak sekali industri-industri rumah tangga (baik industri jasa maupun industri barang jadi) yang tumbuh dan berkembang dengan pesat dan yang berada di dalam daerah yang diperuntukkan sebagai daerah pemukiman.

Jenis industri atau usaha yang paling banyak dikembangkan oleh masyarakat adalah bengkel kendaraan bermotor, klinik kesehatan berikut dengan rumah obatnya, produksi tahutempe, salon kecantikan, usaha laundry atau pencelupan bahan sandang (jeans), rumah makan (warung tegal) dan usaha pelapisan logam (Nikel-Chrom Electroplating). Kenyataan tersebut sudah jelas menunjukkan bahwa telah terjadi penyimpangan yang sangat besar dan bila berpegang pada peraturan yang berlaku, seharusnya pelaku usaha tersebut dikenakan sangsi pidana atau terkena hukuman. Sebagai contoh saja, di Kecamatan Jatinegara banyak areal pemukiman yang telah berubah fungsi menjadi daerah niaga atau pertokoan. Demikian juga untuk Kecamatan Cibubur, Ciracas dan banyak lagi kecamatan lain yang telah kewalahan mengatur perkembangan di sektor informal ini.

Demikian juga halnya yang terjadi di Kelurahan Sukabumi Selatan, Wilayah Jakarta Barat, yaitu terjadinya pencemaran air permukaan dan air tanah penduduk akibat limbah yang terolah dari sekitar 46 (empat puluh enam) industri rumah tangga yang memproduksi pakaian jadi dari bahan jean kualitas ekspor ke mancanegara. Seluruh industri tekstil tersebut tidak ada yang mempunyai instalasi pengolahan air limbah dan rata-rata mereka memompa air tanah dalam sebanyak $90 \mathrm{~m}^{3}$ setiap harinya untuk keperluan proses produksi dan pencuciannya. Jadi setiap hari paling sedikit $4.000 \mathrm{~m}^{3}$ air limbah tak terolah yang berwarnawarni (hijau, hitam, biru dan coklat) menggelontor saluran drainase kota dan terus mengalir menuju Sungai Pesanggrahan.

Bahan pencemar yang dominan dalam limbah cair tersebut adalah kandungan padatan tersuspensi, warna dan sabun atau deterjen dengan beban COD berkisar antara 3.000 (tiga ribu) sampai dengan 5.000 ppm.6) Sejauh ini Dinas Perindustrian dan BPLHD Jakarta Barat telah melakukan pembinaan operasional dan manajemen untuk industri tekstil/jean tersebut, namun sampai akhir tahun 2008 ini ternyata tidak terdapat kemajuan berarti dalam penanggulangan masalah pencemaran air di kawasan Kelurahan Sukabumi Selatan. Alternatif yang muncul dari Pemerintah Daerah adalah kemungkinan untuk merelokasi industri-industri rumah tangga tersebut dan membangun sistem/instalasi pengolahan air limbah (IPAL) secara terpadu atau berskala komunal.5) Alternatif kedua rupanya mendapat tentangan dari para pengusaha industri, karena dibutuhkan biaya investasi dan operasional yang tinggi untuk IPAL. Sedangkan alternatif pertama juga akan membawa implikasi yang kompleks, karena pemindahan ke lokasi yang jauh (rencananya di kawasan industri di Bekasi) akan berakibat mobilisasi yang juga membutuhkan biaya tinggi dan berdampak sosial, terutama bagi para buruh yang rata-rata adalah penduduk asli.

Penyimpangan-penyimpangan yang terjadi tersebut diperparah lagi dengan ketidak-tahuan dan ketidak-mampuan para pelaku usaha dalam menjalankan usahanya dengan syarat-syarat tertentu yang mengacu pada konsep pembangunan berwawasan lingkungan. Artinya, bahwa para pelaku bisnis tersebut tidak mampu untuk mengoperasikan proses produksinya dengan benar, yaitu yang tidak menimbulkan dampak negatif terhadap lingkungan hidup dan potensi sumber daya alam sekitarnya. Karena itu yang terjadi adalah berbagai kasus pencemaran dan perusakan lingkungan yang sudah tidak terkendali lagi.

Apabila hal ini didiamkan terus, maka dapat dipastikan bahwa daya dukung alam pasti akan terus merosot dengan tajam dan akibat lanjutannya adalah bencana bagi manusia dan segala mahluk hidup karena menderita berbagai macam penyakit akibat teracuni oleh bahanbahan pencemar, baik bahan kimia ataupun bakteri/virus patogen. Situasi dan kondisi seperti ini benar-benar menjadi beban yang sangat berat bagi Pemerintah Daerah, karena memang segala urusan yang menyangkut pelayanan terhadap masyarakat atau publik pada umumnya ditangani oleh pemerintah.

\section{KAJIAN ASPEK KEBIJAKAN dan REGULASI DALAM PENGELOLAAN LIMBAH CAIR INDUSTRI RUMAH TANGGA}

\subsection{Peraturan Pengelolaan Lingkungan Kegiatan Industri Rumah Tangga}

Untuk mengatasi permasalahan tersebut dibutuhkan penyempurnaan kebijakan pemerintah daerah/kota dan peraturan daerah yang merupakan perangkat utama dalam sistem 
pengelolaan lingkungan, yaitu dengan disusunnya Peraturan Pengelolaan Lingkungan Kegiatan Industri Rumah Tangga. Dengan mengacu pada peraturan-peraturan yang sudah ada sebelumnya, seperti UU Lingkungan Hidup, Peraturan Pemerintah, Keputusan Menteri Negara Lingkungan Hidup dan Peraturan Daerah Provinsi DKI Jakarta, maka kiranya masih diperlukan pengembangan dan penyempurnaan Peraturan Daerah atau Regulasi, baik pada tingkat provinsi ataupun daerah tingkat II (setingkat kabupaten), terutama yang berkaitan erat dengan masalah sistem pengelolaan limbah pada umumnya dan khususnya untuk limbah cair industri rumah tangga. Berikut ini adalah peraturan-peraturan (sesuai dengan hierarkinya) yang berkaitan dengan pengelolaan lingkungan dan pengelolaan limbah cair industri rumah tangga, serta yang selayaknya dijadikan acuan utama dalam menyempurnakan PeraturanPeraturan Daerah tersebut.

\section{a) Undang-Undang Republik Indonesia}

- Undang-undang RI Nomor 5 tahun 1990 tentang Konservasi Sumber Daya Alam Hayati dan Ekosistemnya.

- Undang-undang RI Nomor 23 tahun 1992 tentang Kesehatan.

- Undang-undang RI Nomor 24 tahun 1992 tentang Penataan Ruang.

- Undang-undang RI Nomor 23 tahun 1997 tentang Pengelolaan Lingkungan Hidup.

- Undang-undang RI Nomor 18 tahun 1999 tentang Jasa Konstruksi.

- Undang-undang RI Nomor 32 tahun 2004 tentang Pemerintah Daerah.

- Undang-undang RI Nomor 18 tahun 2008 tentang Pengelolaan Sampah.

b) Peraturan Pemerintah / Keputusan Presiden Republik Indonesia

- Peraturan Pemerintah No. 15 tahun 1989 tentang AMDAL dan Penyehatan Lingkungan

- Peraturan Pemerintah Nomor 13 tahun 1996 tentang Izin Usaha Industri.

- Peraturan Pemerintah Nomor 69 tahun 1996 tentang Pelaksanaan Hak dan Kewajiban serta Bentuk dan Tata Cara Peran Serta Masyarakat dalam Penataan Ruang.

- Peraturan Pemerintah Nomor 35 tahun 1991 tentang Sungai.

- Peraturan Pemerintah Nomor 27 tahun 1999 tentang Analisis Mengenai Dampak Lingkungan.

- Peraturan Pemerintah Nomor 41 tahun 1999 tentang Pengendalian Pencemaran Udara
- Peraturan Pemerintah Nomor 25 tahun 2000 tentang Kewenangan Pemerintah dan Kewenangan Pemerintah Provinsi sebagai Daerah Otonom.

- Peraturan Pemerintah Nomor 150 tahun 2000 tentang Pengendalian Kerusakan Tanah untuk Produksi Biomassa.

- Peraturan Pemerintah No. 28 tahun 2000 tentang Usaha dan Peran Serta Masyarakat JK

- Peraturan Pemerintah No. 29 tahun 2000 tentang Penyelenggaraan JK

- Peraturan Pemerintah No. 30 tahun 2000 tentang Penyelenggaraan Pembinaan JK

- Peraturan Pemerintah Nomor 74 tahun 2001 tentang Pengelolaan B3.

- Peraturan Pemerintah Nomor 82 tahun 2001 tentang Pengelolaan Kualitas Air dan Pengendalian Pencemaran Air.

- Kepres No. 18 tahun 2000 tentang Pedoman Pengadaan B/J Ins. Pem.

c) Keputusan Menteri Negara Lingkungan Hidup

- Keputusan Menteri Negara Lingkungan Hidup Nomor : Kep-42/Menlh/11/1994 tentang Audit Lingkungan.

- Keputusan Menteri Negara Lingkungan Hidup Nomor : 13 tahun 1995 tentang Baku Mutu Emisi Sumber Tidak Bergerak.

- Keputusan Menteri Negara Lingkungan Hidup Nomor : Kep-35A/Menlh/7/1995 tentang Program Penilaian Kinerja dan Perusahaan/Kegiatan Usaha dalam Pengendalian Pencemaran di Lingkup Kegiatan Prokasih (proper Prokasih).

- Keputusan Menteri Negara Lingkungan Hidup Nomor : 51 tahun 1995 tentang Baku Mutu Limbah Cair bagi Kegiatan Industri.

- Keputusan Menteri Negara Lingkungan Hidup Nomor : Kep-48/Menlh/11/1996 tentang Baku Tingkat Kebisingan.

- Keputusan Menteri Negara Lingkungan Hidup Nomor : Kep-49/Menlh/11/1996 tentang Tingkat Getaran.

- Keputusan Menteri Negara Lingkungan Hidup Nomor : Kep-50/Menlh/11/1996 tentang Tingkat Kebauan.

- Keputusan Menteri Negara Lingkungan Hidup Nomor : 02/1/1998 tentang Baku Mutu Lingkungan Debu dan Gas.

- Keputusan Menteri Negara Lingkungan Hidup Nomor : 17 tahun 2001 tentang Jenis Usaha dan/atau Kegiatan Yang Wajib Dilengkapi Dengan Analisis Mengenai Dampak Lingkungan. 
- Keputusan Menteri Negara Lingkungan Hidup Nomor : 45 Tahun 2006 tentang Pedoman Penyusunan Laporan Pelaksana RKL-RPL.

d) Keputusan Menteri Kesehatan

- Peraturan Menteri Kesehatan Nomor : 718/Menkes/Per/XII/1987 tentang Kebisingan yang Berhubungan dengan Kesehatan.

- Peraturan Menteri Kesehatan Nomor : 416/Menkes/Per/IX/1990 tentang SyaratSyarat dan Pengawasan Kualitas Air.

e) Keputusan Badan Pengendalian Dampak Lingkungan

- Keputusan Kepala Badan Pengendalian Dampak Lingkungan Nomor : 205/07/1996 tentang Pedoman Teknis Pengendalian Pencemaran Udara untuk Sumber Tidak Bergerak.

- Keputusan Kepala Badan Pengendalian Dampak Lingkungan Nomor : 105 tahun 1997 tentang Panduan Pemantauan Pelaksanaan Rencana Pengelolaan Lingkungan (RKL) dan Rencana Pemantauan Lingkungan (RPL).

f) Standar Nasional Indonesia (SNI)

- Standar Nasional Indonesia (SNI) Nomor: 06-2421-1991 tentang Metode Pengambilan Contoh Uji Kualitas Air.

g) Surat Keputusan Gubernur atau Bupati/Walikota yang mengatur tentang :

- Baku mutu limbah cair.

- Kualitas atau golongan sungai.

- Tata Ruang wilayah.

- Baku Mutu air.

- SK Gubernur KDKI Jakarta No. 450 tahun 1996 dan No. 2 tahun 2001 tentang Pelaksanaan APBD berikut penyempurnaan dan perubahannya.

- Izin Pembuangan Limbah Cair (Pergub DKI Jakarta Nomor 122 Tahun 2005).

Dengan mengacu pada sistem peraturan dan perundang-undangan tersebut di atas (dari butir a sampai dengan g), maka sepatutnya pihak Pemerintah Daerah, baik di tingkat Provinsi maupun Kabupaten segera menindaklanjuti dengan penyempurnaan-penyempurnaan sistem regulasi terutama yang berkaitan dengan kegiatan industri rumah tangga. Semua hendaknya dilakukan secara bertahap dan dengan koordinasi seluruh potensi kelembagaan yang terkait, serta masyarakat industri itu sendiri.

Bersamaan dengan pengembangan peraturan dan perundang-undangan tentu juga harus dilakukan peningkatan faktor-faktor pendukungnya, misalnya :

- Sarana dan prasarana phisik, seperti laboratorium dan lain-lainnya.

- Perangkat hukum yang berkaitan dengan pelaksanaan proses hukum bagi yang terkena sangsi atau pelanggar hukum.

\subsection{Standar Prosedur Pengelolaan Limbah Industri Rumah Tangga}

Berdasarkan survey lapangan langsung ke lokasi-lokasi industri rumah tangga yang ada di Wilayah Jakarta Timur diketahui bahwa masih banyak permasalahan lingkungan yang terjadi di dalam areal pemukiman, maupun di dalam pabrik pengolahan untuk memproduksi baik jasa atau barang. Karena itu dibutuhkan suatu Standar Prosedur Operasional Pengelolaan Limbah Industri Rumah Tangga untuk setiap jenis industri atau usaha. Akibat tidak adanya standardisasi ini, maka tanpa disadari betul terus terjadi penyimpangan-penyimpangan dalam pengelolaan limbah industri rumah tangga ini.

Dapat dibayangkan bahwa apabila masalah ini dibiarkan dan tidak segera ditangani dengan cepat, maka masalah pencemaran lingkungan akan semakin terakumulasi dan suatu saat akan menyebabkan menurunnya kualitas dan potensi sumber daya alam secara significant. Pengelolaan yang baik salah satunya tercermin dari diaturnya kegiatan operasional pengelolaan limbah dalam sebuah standar operasi. Dalam standar operasi tersebut haruslah mencakup setiap tahapan kegiatan yang harus dilakukan oleh operator pengelolaan limbah untuk mengendalikan, mengalirkan, mengolah limbah hingga melakukan kegiatan pencatatan dan dokumentasi.

Berkenaan dengan masalah tersebut, BPLHD (Badan Pengelola Lingkungan Hidup Daerah) baik tingkat Provinsi ataupun tingkat wilayah hendaknya menyusun Buku Panduan "Standar Prosedur Operasional (SPO) Pengelolaan Limbah Industri Rumah Tangga". Konsep dasar SPO Pengelolaan Limbah Industri Rumah Tangga tersebut mengacu pada pengelolaan limbah yang terintegrasi dan mengedepankan pendekatan minimisasi limbah, produksi bersih dan pemanfaatan limbah.

\subsection{Kebijakan dan Regulasi di Bidang Baku Mutu Air Limbah}

Sesuai dengan peraturan dari Pemerintah Pusat, setiap daerah atau kota harus memiliki peraturan tentang baku mutu air limbah sebagai perangkat pengendalian pembuangan air limbah. 
Air limbah yang melebihi baku mutu akan mengakibatkan terjadinya pencemaran lingkungan, khususnya pencemaran pada badanbadan air, baik air permukaan maupun air tanah. Pemerintah DKI Jakarta telah mengeluarkan kebijakan tentang Baku Mutu Air Limbah Industri rumah tangga melalui Peraturan Gubernur tentang Pengelolaan Air Limbah Industri rumah tangga. Baku mutu limbah cair industri rumah tangga yang disyaratkan baru untuk beberapa jenis industri saja. Secara nasional.

Peraturan yang mengatur baku mutu limbah cair industri adalah Keputusan Menteri Negara Lingkungan Hidup Tahun 1995. Namun peraturan inipun belum lengkap untuk berbagai jenis industri. Dengan mengacu pada Keputusan Menteri Negara Lingkungan Hidup tahun 1995 tersebut, masih perlu dikembangkan lagi peraturan yang mengatur baku mutu limbah cair industri, khususnya industri rumah tangga, dan untuk propinsi dan atau wilayah di DKI Jakarta. Sebagai contoh adalah peraturan untuk kegiatan usaha rumah makan atau yang untuk skala kecil (warung tegal). Untuk itu dapat menggunakan acuan Peraturan Baku Mutu Limbah Cair Industri kegiatan Hotel Berbintang (lihat Tabel 1).

Tabel 1. Baku Mutu Limbah Cair Industri Kegiatan Hotel Berbintang 3,4 \& 5

\begin{tabular}{|c|c|}
\hline PARAMETER & KADAR MAKSIMUM (mg/L) \\
\hline \hline $\mathrm{BOD}_{5}$ & 30 \\
$\mathrm{COD}$ & 50 \\
TSS & 500 \\
$\mathrm{pH}$ & $6,0-9,0$ \\
\hline
\end{tabular}

Sumber: Kep. Men. Neg. LH. No.: KEP52/MENLH/10/1995 tentang Baku Mutu Limbah Cair Bagi Kegiatan Hotel, tanggal 23 Oktober 1995. ${ }^{3)}$

Dengan cara yang sama, dapat dikembangkan peraturan-peraturan baku mutu limbah cair industri untuk jenis-jenis industri yang lain.

\subsection{Kebijakan dan Regulasi di Bidang Teknik Pengelolaan Limbah Cair Industri Rumah Tangga}

Seperti halnya Peraturan Gubernur Provinsi Daerah Khusus Ibukota Jakata Nomor 122 Tahun 2005 tentang Pengelolaan Air Limbah Domestik di Provinsi Daerah Khusus Ibukota Jakarta, maka untuk pengelolaan limbah cair industri rumah tangga juga sebaiknya diatur dengan peraturan gubernur. $\mathrm{Di}$ dalam pengelolaan limbah cair telah mencakup pengolahan limbah cair. Karena itu di dalam peraturan gubernur tersebut juga tercakup syarat-syarat teknis, misalnya tentang teknologi proses yang digunakan, atau bahkan sampai dengan unit-unit perangkat pemrosesnya. Namun harus dicermati, bahwa setiap limbah cair dari suatu jenis industri tertentu pasti mempunyai karakteristik berbeda dengan industri lainnya. Jadi peraturan untuk standar teknis juga harus dibuat per jenis industri rumah tangga yang ada.

\subsection{Kebijakan dan Regulasi di Bidang Tata Ruang dan Bangunan}

Pengelolaan air limbah perkotaan baik skala kota maupun komunal membutuhkan ruang untuk lokasi IPAL dan sistem jaringan air limbah, sehingga pelaksanaan kegiatan pengelolaan air limbah kota sangat terkait dengan kebijakan dan peraturan di bidang tata ruang kota tersebut. Kebijakan Pemda DKI Jakarta di bidang tata ruang dan bangunan telah dirumuskan dalam Peraturan Daerah DKI Jakarta No. 6 Tahun 1999 tentang Rencana Tata Ruang Wilayah DKI Jakarta 2010. Adapun kebijakan tata ruang yang berkaitan dengan pengelolaan air limbah untuk kota tercantum dalam Pasal 23 Perda tersebut, yaitu sebagai berikut :

1. Pengembangan prasarana air limbah untuk meminimalkan tingkat pencemaran pada badan air dan tanah serta peningkatan sanitasi kota melalui pengaturan fungsi drainase.

2. Memperluas pelayanan pengelolaan air limbah dengan sistem perpipaan tertutup melalui pengembangan sistem terpusat di kawasan pemukiman, kawasan pusat bisnis, kawasan industri dan pelabuhan.

3. Pengembangan sistem modular dengan teknologi terbaik yang dapat diterapkan.

4. Pelayanan pengolahan air limbah direncanakan melalui pembagian zona-zona pelayanan sebagai berikut :

- Zona tengah utara dengan lingkup pelayanan seluas $4.300 \mathrm{Ha}$

- Zona tengah selatan dengan lingkup pelayanan seluas $1.800 \mathrm{Ha}$

- Zona barat laut dengan lingkup pelayanan seluas $2.020 \mathrm{Ha}$

- Zona barat daya dengan lingkup pelayanan seluas $2.170 \mathrm{Ha}$

- Zona tenggara dengan lingkup pelayanan seluas $1.240 \mathrm{Ha}$

- Zona timur laut dengan lingkup pelayanan seluas $3.570 \mathrm{Ha}$

- Zona Tanjung Priok dengan lingkup pelayanan seluas $1.500 \mathrm{Ha}$ 
Pembagian zona-zona pelayanan tersebut dapat dilihat pada Gambar 1.

5. Setiap zona pelayanan dilayani oleh pusat IPAL skala kota dengan total luas lahan yang dialokasikan seluas $800 \mathrm{Ha}$, yang terdistribusi sebanyak 2 buah di wilayah Jakarta Barat, 1 buah di wilayah Jakarta Selatan, 1 buah di wilayah Jakarta Timur, dan 3 buah di wilayah Jakarta Utara seperti dapat dilihat pada gambar tersebut.

Selanjutnya, bila dikaitkan dengan standar kebutuhan ruang kota untuk pengolahan limbah cair, maka dengan jumlah penduduk DKI Jakarta 12.500.000 jiwa pada tahun 2010 dibutuhkan sekitar $3 \mathrm{~km}^{2}$ atau $300 \mathrm{Ha}$ ruang untuk pengolahan 2.876.450 $\mathrm{m}^{3}$ / hari air limbah yang dihasilkan. Dengan demikian, ruang yang dialokasikan dalam RTRW seluas $800 \mathrm{Ha}$ sebenarnya sudah memadai untuk instalasi pengolahan limbah cair domestik dan industri rumah tangga di Jakarta. Dengan demikian untuk meningkatkan kapasitas pengolahan IPAL, dibutuhkan kebijakan untuk mengolah limbah dimulai dari sumber, baik skala individual maupun komunal.

Kebijakan tersebut perlu didukung oleh penyediaan teknologi IPAL sederhana yang dapat disediakan sendiri oleh masyarakat. Selain itu, kebijakan untuk mengembangkan pembangunan unit pengolahan limbah cair sistem komunal pada kawasan pemukiman padat dan kumuh selain dihadapkan pada kesulitan memperoleh lahan, tidak sesuai dengan kebijakan pengelolaan air limbah dalam Peraturan Gubernur yang melarang penggunaan septic tank dan menggantinya dengan IPAL/STP.

\subsection{Kebijakan dan Regulasi di Bidang Kelembagaan}

Untuk pengelolaan limbah cair industri rumah tangga di DKI Jakarta belum ditegaskan dalam peraturan tentang lembaga pemerintah mana yang bertanggung-jawab dan mempunyai kewenangan penuh. Yang sementara ini berjalan tampak bahwa berbagai dinas dan badan berjalan sendiri-sendiri. Sebut saja Dinas Kebersihan Jakarta Timur memiliki kapasitas sebagai pengelola IPAL di Pulo Gebang, sementara itu untuk Jakarta Pusat dikelola oleh PD. PAL Jaya, dan masih ada lagi Dinas Perumahan yang juga mengatur pengelolaan limbah cair industri rumah tangga untuk beberapa wilayah perumahan.

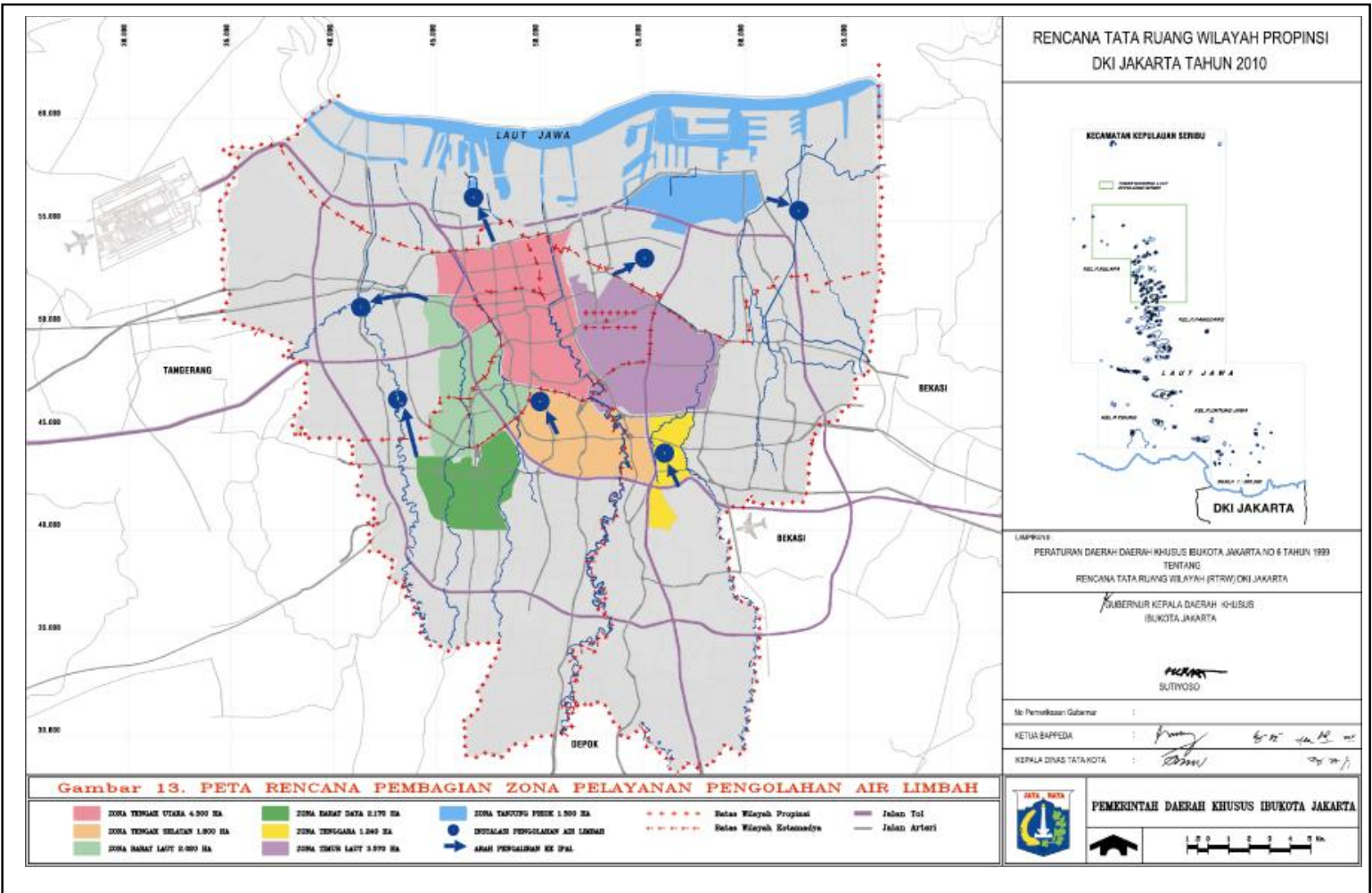

Sumber : RTRW DKI Jakarta $2010^{4)}$

Gambar 1. Peta Rencana Pembagian Zona Pelayanan Pengelolaan Air LImbah Di Propinsi DKI Jakarta 
Lembaga-lembaga lain yang juga turut menangani adalah Dinas Perindustrian dan Perdagangan, Dinas Pekerjaan Umum, BPLHD, Dinas Tata Kota, Dinas Kesehatan dan Dinas Penataan dan Pengawasan Bangunan, serta Tim Penasehat Instalasi dan Kelengkapan Bangunan. Karena itu masih dibutuhkan suatu aturan yang dapat mengkoordinasikan seluruh instansi pemerintah yang terkait agar tidak terjadi friksi kewenangan dan tanggung-jawab antar instansi.

\section{PENUTUP}

\subsection{Kesimpulan}

Secara umum, baik sistem maupun materi peraturan atau perundang-undangan yang ada sebenarnya sudah sangat memadai untuk mencegah dan atau menanggulangi masalah pencemaran lingkungan pada umumnya. Bahkan produk peraturan dari Pemerintah Pusat dan DPR, yaitu Undang-Undang Republik Indonesia Nomor 18 Tahun 2008 tentang Pengelolaan Sampah, khususnya di perkotaan telah menunjukkan suatu perhatian yang sangat besar terhadap upaya yang harus dilakukan dalam pencegahan pencemaran air (air tanah atau air permukaan) akibat adanya air lindi (leachate) yang ditimbulkan oleh adanya timbunan sampah perkotaan di TPAS (Tempat Pemrosesan Akhir Sampah).

Demikian halnya dengan kebijakankebijakan dan peraturan-peraturan yang telah dikeluarkan oleh berbagai Pemerintah Daerah di Indonesia yang juga sudah menunjukkan arah yang jelas dalam penanggulangan masalah pencemaran air. Hal itu ditunjukkan oleh adanya kebijakan dan regulasi yang telah mencakup berbagai aspek, seperti : Pengelolaan Lingkungan Kegiatan IRT (Industri Rumah Tangga); Standar Prosedur Pengelolaan Limbah IRT; Bidang Baku Mutu Air Limbah; Bidang Teknik Pengelolaan Limbah Cair IRT; Bidang Tata Ruang \& Bangunan; dan Bidang Kelembagaan.

Salah satu kelemahan yang terlihat dalam pelaksanaan di lapangan adalah lemahnya koordinasi antar lembaga, baik di antara lembaga-lembaga pemerintah maupun dengan lembaga swadaya masyarakat yang ada. Kelemahan ini mengakibatkan ketidak-efisienan dalam menanggulangi masalah pencemaran lingkungan. Hal itu dapat ditunjukkan dari banyaknya program-program yang bertumpuk dalam satu kegiatan sosialisasi atau penyuluhanpenyuluhan tentang pengelolaan lingkungan, namun di lain pihak seperti untuk kepentingan monitoring atau pemantauan kualitas lingkungan air secara berkala ternyata belum ada sinkhronisasi program antar lembaga, sehingga banyak terjadi pencemaran lingkungan yang tidak terpantau.

\subsection{Saran}

Walaupun sistem peraturan dan perundang-undangan tentang atau yang berkaitan dengan pengelolaan limbah cair IRT di Indonesia pada umumnya sudah sangat memadai, namun tetap perlu dilakukan penyempurnaan-penyempurnaan, terutama dalam hal aplikasinya (law enforcement). Agar implementasi peraturan-peraturan di segala bidang lingkungan tersebut dapat diimplementasikan dengan baik, dibutuhkan perangkat hukum yang memadai, serta peningkatan kualitas dan kuantitas sumber daya manusianya (SDM). Dengan demikian segala bentuk pelanggaran terhadap peraturanperaturan tersebut akan segera dapat diproses secara hukum dan apabila memang terbukti bersalah karena mencemarkan lingkungan, maka yang bersangkutan akan segera dikenakan sangsi sesuai hukum yang berlaku. Bila segala aspek hukum ini telah berjalan dengan baik, maka niscaya pasti berakibat positif terhadap upaya penanggulangan pencemaran lingkungan.

Koordinasi kelembagaan, berikut dengan pendanaannya untuk kepentingan pengelolaan dan pemantauan lingkungan, harus pula lebih diintensifkan, sehingga kualitas lingkungan dapat secara terus menerus dapat terjaga dan diketahui kondisinya.

\section{DAFTAR PUSTAKA}

1. NN, "Rumah Tangga di DKI Jakarta Wajib Kelola Limbah", Kompas, Jakarta, Kamis, 17 Maret 2005.

2. NN, "Pencemaran Air Jakarta", Dinas PU Provinsi DKI Jakarta Raya, 2005.

3. NN, "Kep. Men. Neg. LH. No.: KEP52/MENLH/10/1995 tentang Baku Mutu Limbah Cair Bagi Kegiatan Hotel", tanggal 23 Oktober 1995.

4. NN, "Rencana Tata Ruang Wilayah DKI Jakarta", Dinas Tata Kota Provinsi DKI Jakarta Raya, 1999.

5. P. Nugro R. \& Taty Hernaningsih, "Strategi Penerapan Teknologi Pengolahan Limbah Cair Domestik, Studi Kasus di Jakarta Pusat", Kementerian Negara Riset dan Teknologi Republik Indonesia, 2005.

6. Nusa I.S., dkk., "Penerapan Teknologi Pengolahan Limbah Cair Industri Pencelupan Jean di Kelurahan Sukabumi Selatan, Jakarta Barat", Pusat Pengkajian dan Penerapan Teknologi Lingkungan, BPPT, Jakarta, 2005. 